\title{
Soft Food Paradox: Cost Analysis of Food Leftovers and Preferences in Chronic \& Acute Patients
}

\author{
Dhini, Utari DI \\ Department of Nutrition, Poltekkes Kemenkes Palangka Raya, Indonesia \\ *Corresponding Author: Dhini, Department of Nutrition, Poltekkes Kemenkes Palangka Raya, \\ Indonesia, E-mail: dhini.anden@polttekkes-palangkaraya.ac.id
}

\begin{abstract}
This article aims to identify cost of soft food leftovers among chronic and acute patients - a paradox, given the sufficient nutrition necessary these patients face. This research is analytic descriptive with cross sectional research design with the subjects of the study the 14-64 years old patients who had been treated for 1 day $(n=34)$. The leftover of the lunch was measured using the Comstock method. The remaining lunch costs are derived from the cost of remaining unhealthy soft foods and Fisher's Exact Test was used. Length of stay, type of disease, leftovers of staple food, animal side dishes, vegetable side dishes, vegetable, and fruits are considered as the causes of soft food leftovers. However, the result indicates that no significant association found between the soft foods leftovers with the type of disease, the length of stay and vegetable side dishes. But the significant association exists in leftovers of staple foods, animal side dishes, vegetables and fruits. With the average lunch leftovers in a day is 27.64\%, the cost of soft foods at lunch lost a day Rp. 1,871.92 / patient, then the cost of food leftovers in a year is Rp. 673.891,64 / patient. Since most government hospitals in Indonesia are low-budget, any behavioral change in this area is likely to have a considerable impact in maintaining the operation cost.
\end{abstract}

Keywords: Food leftovers, Length of stay, Disease types, Cost of food leftover

\section{INTRODUCTION}

The organization of hospital food is a series of activities ranging from the establishment of hospital feeding regulations, menu planning, to the distribution of food to patients / consumers in order to achieve optimal health status through the provision of proper diet (Depkes RI, 2007).

Food leftover data is generally used to evaluate the effectiveness of nutritional counseling programs, food delivery and services, and the adequacy of food consumption in groups or individuals (Djamaluddin, 2002). Research conducted by Ariefuddin et. al (2009) shows that the increasing gap of soft food portion served to the respondents to the standard portion of hospital soft foods resulting in the more food leftover. Research in Hasan Sadikin Hospital Bandung Indonesia revealed that the average of adult food remnants was $28.045 \%$ consisting of $13.09 \%$ usual food leftover and $43 \%$ inedible soft food (Instalasi Gizi RSHS, 2009). Furthermore the research conducted on 91 adult patients in the inpatient room of the same hospital indicated that the average of soft food waste was $28.42 \%$ (Haerani, 2012). This result ARC Journal of Nutrition and Growth is higher than the Minimum Service Standard indicator or Standar Pelayanan Minimal required for hospital nutrition service which is < 20\% (Depkes RI, 2007).

The high soft food leftover will result not only in the cost of wasted food, but also the rest of the food wasted leads to inappropriate nutrition supply that should be obtained by patients. In addition to impacting on cost efficiency, high food remnants also show the increased patient dissatisfaction toward portion of food being served. According to Almatsier (1992) other factors affecting food waste are gender, education level, age group, treatment class, length of treatment and illness. Realizing cost efficiency is of paramount important in the hospital operation, the researchers are interested in analyzing the cost of soft food leftover in one of Palangka Raya, Indonesia hospitals.

\section{MATERIALS AND METHOdS}

The scope under study is institutional nutrition with observation aiming to find out the cost of soft food leftover during lunch time among internal disease patients treated in wards of the

Page $\mid 7$ 
hospital. Cross section design was applied to identify the measurement of food remnants in pre-pre-determined and collected patients where at the same time the cost of the food leftovers was then analyzed. The object of the study was all the rest of the soft foods in 1 (one) menu cycle for ten days in patients undergoing hospitalization at the Internal Medicine Room at XYZ Hospital, Palangka Raya, Indonesia. Using purposive sampling method, the inclusion criteria of respondents are: aged 14-64 years; received oral food with soft foods (ordinary porridge and soft rice); and a minimum one day treatment for new patients.

Data is processed with Fisher's Exact Test with 95\% confidence level using Statistical Product and Service Solutions (SPSS). Fisher's exact test is more accurate than the chi-square test or $G-$ test of independence when the expected numbers are small and is recommended to use when the total sample size is less than 1000 (McDonald, 2009)

\section{RESUlT AND DISCUSSION}

Table 1 shows the frequency distribution of age, gender and length of stay.

Table1. Frequency distribution of respondent characteristic.

\begin{tabular}{|c|c|c|}
\hline \multirow{2}{*}{ Variable } & \multicolumn{2}{|c|}{ Total } \\
\hline & $\mathbf{n}$ & $\%$ \\
\hline \multicolumn{3}{|l|}{ a. Ages } \\
\hline $14-44$ years & 19 & 55.9 \\
\hline $45-54$ years & 8 & 23.5 \\
\hline $55-64$ years & 7 & 20.6 \\
\hline \multicolumn{3}{|l|}{ b. Genders } \\
\hline Men & 12 & 35.3 \\
\hline Women & 22 & 64.7 \\
\hline \multicolumn{3}{|l|}{ c. Length of Stay } \\
\hline$>5$ days & 11 & 32.4 \\
\hline$\leq 5$ days & 23 & 67.6 \\
\hline
\end{tabular}

Types of disease affect the patient's acceptance of food due to high stress factors and types of treatment received resulting in the decreased appetite that making some food left untouched. The diseases in this case are classified into acute and chronic diseases. The acute ones includes gastritis, dyspepsia, dengue fever, anemia and febris while the chronic ones are chronic kidney disease (CKD), congestive heart failure (CHF), diabetes mellitus and cirrhosis hepatitis. Types of diet given for the hospitalized patients are the $26.5 \%$ high-calorie and high protein diets.

Food leftovers were both dietary and non-diet foods consisting of staple foods, animal side dishes, vegetable side dishes, vegetables, and fruit where observation results obtained patients' leftovers varied in each type. The food leftovers were then grouped into 2 types: high if the percentage of food waste is $>25 \%$ and low if the percentage of the remaining food is $\leq 25 \%$. Under that category, $61.76 \%$ of staple food had high leftovers, $55.88 \%$ of animal side dishes had low leftovers, $55.82 \%$ of vegetable side dishes had low leftovers, $64.71 \%$ of vegetable had high leftovers and $85.29 \%$ of fruit had low leftovers.

Table2. Relationship between Type of Diseases and Soft Food Leftovers.

\begin{tabular}{|c|c|c|c|c|c|c|c|c|}
\hline \multirow{3}{*}{ No } & \multirow{3}{*}{ Variables } & \multicolumn{4}{|c|}{ Type of Diseases } & \multirow{2}{*}{\multicolumn{2}{|c|}{ Total }} & \multirow{3}{*}{$\begin{array}{c}p- \\
\text { value }\end{array}$} \\
\hline & & \multicolumn{3}{|c|}{ Chronic } & \multirow{2}{*}{\begin{tabular}{|l|l|}
$\begin{array}{c}\text { Acut } \\
\text { e }\end{array}$ \\
$\mathbf{n}$ & $\%$ \\
\end{tabular}} & & & \\
\hline & & $\mathbf{n}$ & 0 & $\%$ & & $\mathbf{n}$ & $\%$ & \\
\hline 1 & $\begin{array}{l}\text { Main food } \\
\text { leftovers } \\
>25 \% \\
\leq 25 \%\end{array}$ & $\begin{array}{l}11 \\
10\end{array}$ & $\begin{array}{c}52 . \\
4 \\
47 . \\
6\end{array}$ & $\begin{array}{c}10 \\
3\end{array}$ & $\begin{array}{l}76.9 \\
23.1\end{array}$ & $\begin{array}{l}21 \\
13\end{array}$ & $\begin{array}{l}100 \\
100\end{array}$ & 0.276 \\
\hline 2 & \begin{tabular}{|} 
Animal Side \\
Dishes \\
Leftovers \\
$>25 \%$ \\
$\leq 25 \%$
\end{tabular} & $\begin{array}{l}9 \\
12\end{array}$ & $\begin{array}{c}42 . \\
9 \\
57 . \\
1\end{array}$ & $\begin{array}{l}6 \\
7\end{array}$ & $\begin{array}{l}46.2 \\
53.8\end{array}$ & $\begin{array}{l}15 \\
19\end{array}$ & $\begin{array}{l}100 \\
100\end{array}$ & 0.851 \\
\hline 3 & $\begin{array}{c}\text { Vegetable } \\
\text { Side Dishes } \\
\text { Leftovers } \\
>25 \% \\
\leq 25 \%\end{array}$ & $\begin{array}{c}6 \\
15\end{array}$ & $\begin{array}{c}28 . \\
6 \\
71 \\
4\end{array}$ & $\begin{array}{l}8 \\
5\end{array}$ & $\begin{array}{l}61.5 \\
38.5\end{array}$ & $\begin{array}{l}14 \\
20\end{array}$ & $\begin{array}{l}100 \\
100\end{array}$ & 0.058 \\
\hline 4 & $\begin{array}{l}\text { Vegetable } \\
\text { Leftovers } \\
>25 \% \\
\leq 25 \%\end{array}$ & $\begin{array}{c}15 \\
6\end{array}$ & $\begin{array}{c}71 . \\
4 \\
28 . \\
6\end{array}$ & $\begin{array}{l}7 \\
6\end{array}$ & $\begin{array}{l}53.8 \\
46.2\end{array}$ & $\begin{array}{l}22 \\
12\end{array}$ & $\begin{array}{l}100 \\
100\end{array}$ & 0.462 \\
\hline 5 & $\begin{array}{c}\text { Fruit } \\
\text { Leftovers } \\
>25 \% \\
\leq 25 \%\end{array}$ & $\begin{array}{c}4 \\
17\end{array}$ & $\begin{array}{c}19 . \\
0 \\
81 . \\
0\end{array}$ & $\begin{array}{c}1 \\
12\end{array}$ & $\begin{array}{c}7.7 \\
92.3\end{array}$ & $\begin{array}{c}5 \\
29\end{array}$ & $\begin{array}{l}100 \\
100\end{array}$ & 0.627 \\
\hline
\end{tabular}

Nutritional value of food leftover were then calculated to seek how much nutrient was wasted by calculating the nutritional value of the patient's food waste. The average nutritional needs of lunch for each patient is the energy of 478. $39 \mathrm{kcal}$, protein 28.09 grams, fat 14.05grams and carbohydrates 79.73 grams. From the research results obtained, the average nutrient wasted every lunch in a day per person was for energy $104.79 \mathrm{kcal}, 6.71$ grams of protein, 3.07 grams of fat and 27.05 grams of carbohydrate. This way, the amount of nutrient supplied for energy was only $(478.39 \mathrm{kcal}$ $104.79 \mathrm{kcal})=373.6 \mathrm{kcal}$ which means only $78 \%$ of the total kcal or less $22 \%$ of need. By the same token it is found that the protein is less 
$24 \%$, fat is $22 \%$ and carbohydrate is $33 \%$. The cost of remaining soft food was then calculated by converting from the weight of the gram that has been estimated using the visual estimates of the 6-point Comstock scale (1982) into raw weight then converted to gross weight then finally it is converted into Indonesian currency (Rupiah).

The cost of lunch per person in a day according to the group that has the highest price was on the fruit $=$ Rp. 4.792,86, - and the lowest cost was on the vegetable side $=$ Rp. 872, 03, -. The cost of lunch lost per person in a day according to group known was on the animal side dishes = Rp. 841.96, - and the least wasted cost was on a vegetable side dishes that is Rp. 98.03. Once added, the total cost of meal lost in a day is Rp. $1,871,92$, per person - and the calculation in a year will be obtained cost of eating wasted per person is Rp. 673,891.64, -.

Based on the results of Fisher's Exact Test statistics it is known that there is no significant relationship between patient's disease type with the leftovers of main food, animal side dishes, vegetable side dishes, vegetable and fruit as $p$ value is $>0.05$.

The presence of food leftovers is likely to occur because the patient has a high level of stress either caused by the illness being suffered or the medical therapy obtained resulting in decreased appetite, physical activity and altered mental condition (Almatsier, 1992).

The more influential factor is the presence of digestive tract disorders that will affect the appetite. This is confirmed by the results of research Dwiyanti \& Hadi (2003) indicating that there is influence of gastrointestinal symptoms on food intake of patients during hospitalization. Symptoms of this gastrointestinal disorder include nausea, vomiting, bloating, no appetite and diarrhea. This results in the large amount of food that patients do not consume. Thus, one of the causes of food waste is a disease factor suffered by the patient.

Furthermore, the results of this study are in line with the research of Ariefuddin et.al (2009) showing there is no significant relationship between the leftovers of the animal side dishes, vegetable side dishes, vegetables and fruits to the type of patient illness. But this research finds out that for main food has a significant relationship with the type of disease. The possibility of no relation to the leftovers of the main food, animal side dishes, vegetable side dishes, vegetables and fruits with type of disease because there are other causes that are more influential which is the appetite of the patient which according to Mukrie et. al (1990) that the eating habits of patients will affect the appetite of the patient. Serving this way patients tend to spend the food served. Conversely, if not in accordance with the patients' eating habits, the appetite of the patient will decrease and it takes time to adjust. Moehyi (1999) also suggests that appetite will usually be strongly influenced by the condition and state of the patient because in general the patient feels sad and worried by the illness and the lack of movement due to certain diseases. This often leads to hopelessness that eventually causes the patient to lose appetite. The second factor is the food served tends to occur repetition of the material in the adjacent period. For example, in vegetables are carrots and long beans and proved in this study that most of the remaining food is vegetables. This is in line with the study of Hall et.all (2011) stated that vegetables is also the most satiated menu of patients $(47.10 \%)$ and fruit is the least food left by the patient (11.07\%). The types of foodstuffs used and the way of processing should vary since repeated use of recipes with similar processing techniques is likely to cause patient boredom. As the theory expressed by Prakoso (1991) that one type of cuisine served many times in a short time will make consumers feel bored, thus, it should be avoided repetition of materials, colors and spices. Djamaluddin et. al (2005) also has a corresponding theory that the amount of vegetable waste due to cooking techniques usually boiled that in the long term will cause a sense of boredom. Patients with long treatment period tend to memorize the food menu, type of food, taste and so on, so that if the processing is less varied it will cause boredom consequently leading to the decreased patient's appetite and the food served is not consumed. The third factor is the existence of customs from the area which forbids to eat the menu. According to Ayoob et.al (2002), one of the factors that influence a person to choose food that is belief and superstition (food belief and food faddism). The fourth factor is the appearance of food during the distribution of food stacked so that for food items that large size sometimes become destroyed and become less attractive. This is because the trolley capacity is less appropriate with the number of patients served so that food must be stacked to be delivered simultaneously. According to the theory of Moehyi (1992) that the form of 
interesting food will provide a special attraction for each food presented. An interesting form of food can increase the acceptance of food so that respondents eat their food up. The more interesting the form of food, the lesser the leftovers will be.

Table3. The Relationship between Length of Stay and Soft Food Leftovers.

\begin{tabular}{|c|c|c|c|c|c|c|c|}
\hline \multirow{3}{*}{ No } & \multirow{3}{*}{ Variables } & \multicolumn{4}{|c|}{ Length of Stay } & \multirow{2}{*}{\multicolumn{2}{|c|}{ Total }} \\
\hline & & \multicolumn{2}{|c|}{$>5$ days } & \multicolumn{2}{|c|}{$\leq 5$ days } & & \\
\hline & & $\mathbf{n}$ & $\%$ & $\mathbf{n}$ & $\%$ & n & $\%$ \\
\hline 1 & $\begin{array}{c}\text { Main food } \\
\text { leftovers } \\
>25 \% \\
\leq 25 \%\end{array}$ & $\begin{array}{l}6 \\
5\end{array}$ & $\begin{array}{l}54.5 \\
45.5\end{array}$ & $\begin{array}{c}15 \\
8\end{array}$ & $\begin{array}{l}65.2 \\
34.8\end{array}$ & $\begin{array}{l}21 \\
13\end{array}$ & $\begin{array}{l}100 \\
100\end{array}$ \\
\hline 2 & $\begin{array}{c}\text { Animal } \\
\text { Side Dishes } \\
\text { Leftovers } \\
>25 \% \\
\leq 25 \%\end{array}$ & $\begin{array}{l}6 \\
5\end{array}$ & $\begin{array}{l}54.5 \\
45.5\end{array}$ & $\begin{array}{c}9 \\
14\end{array}$ & $\begin{array}{l}39.1 \\
60.9\end{array}$ & $\begin{array}{l}15 \\
19\end{array}$ & $\begin{array}{l}100 \\
100\end{array}$ \\
\hline 3 & $\begin{array}{c}\text { Vegetable } \\
\text { Side Dishes } \\
\text { Leftovers } \\
>25 \% \\
\leq 25 \%\end{array}$ & $\begin{array}{l}2 \\
9\end{array}$ & $\begin{array}{l}18.2 \\
81.8\end{array}$ & $\begin{array}{l}12 \\
11\end{array}$ & $\begin{array}{l}52.2 \\
47.8\end{array}$ & $\begin{array}{l}14 \\
20\end{array}$ & $\begin{array}{l}100 \\
100\end{array}$ \\
\hline 4 & $\begin{array}{c}\text { Vegetable } \\
\text { Leftovers } \\
>25 \% \\
\leq 25 \%\end{array}$ & $\begin{array}{l}8 \\
3\end{array}$ & $\begin{array}{l}72.7 \\
27.3\end{array}$ & $\begin{array}{c}14 \\
9\end{array}$ & $\begin{array}{l}60.9 \\
39.1\end{array}$ & $\begin{array}{l}22 \\
12\end{array}$ & $\begin{array}{l}100 \\
100\end{array}$ \\
\hline 5 & $\begin{array}{c}\text { Fruit } \\
\text { Leftovers } \\
>25 \% \\
\leq 25 \%\end{array}$ & $\begin{array}{c}1 \\
10\end{array}$ & $\begin{array}{c}9.1 \\
90.9\end{array}$ & $\begin{array}{c}4 \\
19\end{array}$ & $\begin{array}{l}17.4 \\
82.6\end{array}$ & $\begin{array}{c}5 \\
29\end{array}$ & $\begin{array}{l}100 \\
100\end{array}$ \\
\hline
\end{tabular}

Fisher's Exact Test statistics reveals that there is no significant relationship between the length of hospitalization with the rest of main food, animal side dishes, vegetable side dishes, vegetable and fruit for the $p$-value is $>0.05$. If the food served as patients' needed but not being consumed regularly for a long time, it will cause the deficiency of nutrients leading to hospital malnutrition (Soegih,1998).

Djamaluddin et al. (2005) states that the longer the day of treatment, the rest of the food, especially on vegetable side dishes and vegetable will be more and more filed up. The large number of vegetable and vegetable side dishes due to the boiled cooking techniques that in the long term causes boredom as patients experiencing long treatment period tend to memorize the food menu, type of food, taste and so on that if the processing is less varied will cause boredom that consequently the patient's appetite is reduced and the food served is not eaten up.
In this study, none of the main food, animal side dishes, vegetable side dishes, vegetables and fruits are related to the length of days of hospitalization. The results of this study are consistent with Iswanto's (2013) study indicating that there is no significant relationship between the rest of main foods, animal side dishes, vegetable side dishes, vegetables and fruits against patient duration. This can be due to other factors that are more influential such as the intake of food from outside the hospital as according to research of Komalawati (2005) indicating that the existence of food outside the hospital consumed will make the patient feel full and not consume the food provided by the hospital.

The results of Rizani's research (2013) from the results of interviews about the reasons for not spending the food, some patients say that the appetite is good, but because of the food from outside the hospital obtained from the family making the food served by the hospital is not consumed by the patient. According to Moehyi (1992), food eaten from outside the hospital will affect the occurrence of food leftovers. Hunger that is not immediately addressed in a patient under treatment leads patients to seek additional food from outside the hospital so that the food coming from the hospital is not consumed.

Table4. Relationship between Soft Food Leftovers and Cost of Food Leftovers.

\begin{tabular}{|c|c|c|c|c|c|c|c|}
\hline \multirow{3}{*}{ No } & \multirow{3}{*}{ Variables } & \multicolumn{4}{|c|}{ Food Leftovers } & \multirow{2}{*}{\multicolumn{2}{|c|}{ Total }} \\
\hline & & \multicolumn{2}{|c|}{$\begin{array}{c}\text { Big } \\
\text { Wasted } \\
\text { Cost } \\
\end{array}$} & \multicolumn{2}{|c|}{$\begin{array}{c}\text { Small } \\
\text { Wasted } \\
\text { Cost }\end{array}$} & & \\
\hline & & $\mathbf{n}$ & $\%$ & $\mathbf{n}$ & $\%$ & $\mathbf{n}$ & $\%$ \\
\hline 1 & $\begin{array}{l}\text { Main food } \\
\text { leftovers } \\
>25 \% \\
\leq 25 \%\end{array}$ & $\begin{array}{c}14 \\
1\end{array}$ & $\begin{array}{c}93.3 \\
6.7\end{array}$ & $\begin{array}{c}7 \\
12\end{array}$ & $\begin{array}{l}36.8 \\
63.2\end{array}$ & $\begin{array}{l}21 \\
13\end{array}$ & $\begin{array}{l}100 \\
100\end{array}$ \\
\hline 2 & \begin{tabular}{|c|} 
Animal Side \\
Dishes Leftovers \\
$>25 \%$ \\
$\leq 25 \%$
\end{tabular} & $\begin{array}{c}12 \\
3\end{array}$ & $\begin{array}{l}80.0 \\
20.0\end{array}$ & $\begin{array}{c}3 \\
16\end{array}$ & $\begin{array}{l}15.8 \\
84.2\end{array}$ & $\begin{array}{l}15 \\
19\end{array}$ & $\begin{array}{l}100 \\
100\end{array}$ \\
\hline 3 & \begin{tabular}{|c|} 
Vegetable Side \\
Dishes Leftovers \\
$>25 \%$ \\
$\leq 25 \%$
\end{tabular} & $\begin{array}{l}8 \\
7\end{array}$ & $\begin{array}{l}53.3 \\
46.7\end{array}$ & $\begin{array}{c}6 \\
13\end{array}$ & $\begin{array}{l}31.6 \\
68.4\end{array}$ & $\begin{array}{l}14 \\
20\end{array}$ & $\begin{array}{l}100 \\
100\end{array}$ \\
\hline 4 & $\begin{array}{l}\text { Vegetable } \\
\text { Leftovers } \\
>25 \% \\
\leq 25 \% \\
\end{array}$ & $\begin{array}{c}14 \\
1\end{array}$ & $\begin{array}{c}93.3 \\
6.7\end{array}$ & $\begin{array}{c}8 \\
11\end{array}$ & $\begin{array}{l}42.1 \\
57.9\end{array}$ & $\begin{array}{l}22 \\
12\end{array}$ & $\begin{array}{l}100 \\
100\end{array}$ \\
\hline 5 & $\begin{array}{c}\text { Fruit Leftovers } \\
\quad>25 \% \\
\leq 25 \%\end{array}$ & $\begin{array}{c}5 \\
10\end{array}$ & $\begin{array}{l}33.3 \\
66.7\end{array}$ & $\begin{array}{c}0 \\
19\end{array}$ & $\begin{array}{c}0 \\
100\end{array}$ & $\begin{array}{c}5 \\
29\end{array}$ & $\begin{array}{l}100 \\
100\end{array}$ \\
\hline
\end{tabular}


Furthermore, Fisher's Exact Test proves there is a significant relationship between the rest of main food, animal side dishes and vegetables to the cost of food leftovers ( $\mathrm{p}$-value $<0.05$ ) while other types are not related.

The presence of food waste indicates the inefficiency of the management in implementing the food system. The food cost analysis is one way to evaluate the nutritional services provided in order to further improve the efficiency and effectiveness of the food administration system in the hospital (Arieffuddin, 2009).

The more the amount of food left and the higher the price of the food, the cost of the food will also increase. The possibility of this is due to the large unit price of foodstuffs and the amount of food lost, both from food leftovers and the mismatch of the weight of the respondent's soft food portion (Ariefuddin, 2009).

In this study, the leftovers of the vegetable side dish shows no significant relationship. This is probably due to the cheaper price of vegetable side dishes than the price of other foodstuffs. As the results of Djamaluddin et. al (2005) which states that the cost of filed up staple food, vegetable and vegetable side dishes are cheaper than a few animal and fruit side dishes leftovers as the price of main food, vegetable and vegetable side dishes are cheaper than the price of animal and fruit side dishes.

In this study the total cost of meal per person lost in a day is Rp $1.871,92$, - or $16.25 \%$ of the average daily lunch price per person is $\mathrm{Rp}$ 11.522 , - . Although the percentage of lost food costs is still below $25 \%$ of the average food prices, but this still illustrates the budget meal which is less efficient. The results of this study are not much different from the results of Ariefuddin et. al (2009) obtaining the average cost of daily food remnants per person is Rp. $1.597,64,-$.

When compared with other studies, this is in line with the Iswanto (2013) which shows that there is no relationship between the rest of the vegetable side dishes with the average cost of the respondent during the treatment. For the rest of the staple food, animal side dishes, vegetables and fruits are not in line with the results of these studies. This may due to the different geograpic location that may affect the taste of food consumed during being treated in hospital.

\section{CONCLUSiON}

The average nutrient wasted every lunch in a day per person for energy is less $22 \%$ from the standard set up. By the same token it is found that the protein is less $24 \%$, fat is $22 \%$ and carbohydrate is $33 \%$. However, th research indicates that there is a relationship between the main food, the animal side dishes, the vegetables and the fruit with the cost of the soft food leftover while the leftovers of vegetable side dishes shows no relationship to the cost of soft food wasted. This way, it is necessary to modify the menu so that the arrangement of the already available good menu cycles is becoming better to minimize the remaining food. Pertaining to the still high soft food leftovers, hospital management should provide opportunities for nutritional department person to attend culinary training or conduct comparative studies to other hospitals to improve the quality of nutrition installation services.

\section{REFERENCES}

[1] Ayoob, K. T., Duyff, R. L., \& Quagliani, D. (2002). Position of the American Dietetic Association: food and nutrition misinformation. Journal of the American Dietetic Association, 102(2), 260-266.

[2] Almatsier, S. 1992. Persepsi Pasien Terhadap Makanan di Rumah Sakit. Jurnal Gizi Indonesia volume 17:87-96. Jakarta

[3] Ariefuddin, M.A., Kuntjoro, T. dan Prawiningdyah, Y. 2009. Analisis Sisa Makanan Lunak Rumah Sakit Pada Penyelenggaraan Dengan System Outsourcing di RSUD Gunung Jati Cirebon. Jurnal Gizi Klinik Indonesia, Maret 2009(5)3:133-142.

[4] Yogyakarta: FK UGM, Comstock, E. M., \& Symington, L. E. (1982). Distributions of serving sizes and plate waste in school lunches. Implications for measurement. Journal of the American Dietetic Association, 81(4), 413-422.

[5] Departemen Kesehatan, RI. 2007. Pedoman Penyelenggaraan Makanan Rumah Sakit. Jakarta

[6] Djamaluddin, M. 2002. Analisis Zat Gizi dan Biaya Sisa Makanan Pasien Dengan Makanan Biasa di RSUP Dr. Sardjito Yogyakarta. Tesis. Program Pascasarjana UGM. Yogyakarta

[7] Djamaludin, M., Prawirohartono, E.P. dan Paramastri, I. 2005. Analisis Zat Gizi dan Biaya Sisa Makanan Pada Pasien Dengan Makanan Biasa. Jurnal gizi klinik Indonesia Maret 2005 (1):3:108-112

[8] Dwiyanti, D., \& Hadi, H. (2003). Pengaruh asupan makanan terhadap kejadian malnutrisi 
di Rumah Sakit (Doctoral dissertation, [Yogyakarta]: Universitas Gadjah Mada).

[9] Haerani, Y. 2012. Analisis Biaya Sisa Makanan Lunak dan Zat Gizi Yang Hilang Pada Pasien Dewasa Kelas 3 di RSUP Dr. Hasan Sadikin Bandung. Skripsi. Program Studi Ilmu Gizi Fakultas Ilmu-ilmu Kesehatan Universitas Esa Unggul. Jakarta.

[10] Hall, L., Collins, C. E., Morgan, P. J., Burrows, T. L., Lubans, D. R., \& Callister, R. (2011). Children's intake of fruit and selected energydense nutrient-poor foods is associated with fathers' intake. Journal of the American Dietetic Association, 111(7), 1039-10.

[11] Instalasi Gizi RSHS. 2009. Gambaran Asupan Makanan Pada Pasien Dewasa di RSUP Dr. Hasan Sadikin Bandung.

[12] Iswanto. 2013. Hubungan Sisa Makanan Dengan Lama Rawat Hari Rawat dan Biaya Pasien Peserta JAMKESMAS/JAMPERSAL Diet Makanan Biasa Di Ruang Rawat Inap Kelas III RSUD Raden Mattaher Jambi. Tesis. Yogyakarta : Universitas Gajah Mada

[13] Komalawati, D. 2005. Pengaruh Lama Rawat Inap Terhadap Sisa Makanan Pasien Anak di RSU Dr. Soeradji Tirtonegoro Klaten. Karya Tulis Ilmiah. Program Studi S-1 Gizi Kesehatan. Yogyakarta: FK UGM.

[14] McDonald, J. H. (2009). Handbook of biological statistics (Vol. 2, pp. 173-181). Baltimore, MD: Sparky House Publishing.
[15] Moehyi, S. 1992. Pengaturan Makanan dan Diit Untuk Penyembuhan Penyakit. Jakarta : PT Gramedia Pustaka Utama

[16] Mukrie, N., Ginting, A.B., Ngadiarti, I. 1990. Manajemen Pelayanan Gizi Institusi Dasar. Jakarta : Proyek Pengembangan Pendidikan Tenaga Gizi Pusat dan Akademi Gizi Departemen Kesehatan RI.

[17] Prakoso, M. 1991. Tatalaksana Terapi Diit Pada Pasien Kanker. Jakarta : RSCM

[18] Rizani, A. 2013. Pengaruh Faktor Internal dan Eksternal Terhadap Terjadinya Sisa Makanan Pasien Rawat Inap Di Rumah Sakit Bhayangkara Palembang. Skripsi. Fakultas Kesehatan Masyarakat Universitas Sriwijaya.

[19] Soegih, R. 1998. Pola Penanganan Kasus Gizi di Puskesmas dan Rumah Sakit. Dalam Buku Kapita Selekta Nutrisi Klinik. Jakarta: PERNEPARI.

Citation: Dhini, Utari DI. Soft Food Paradox: Cost Analysis of Food Leftovers and Preferences in Chronic \& Acute Patients. ARC Journal of Nutrition and Growth. 2017;3(1):7-12. doi: dx.doi.org/10.20431/24552550.0301002 .

Copyright: (c) 2017 Authors. This is an open-access article distributed under the terms of the Creative Commons Attribution License, which permits unrestricted use, distribution, and reproduction in any medium, provided the original author and source are credited. 